\title{
Karamzin jako Rus a Evropan: podstatné je v detailu a na okraji
}

\author{
Ivo Pospíšil (Brno)
}

Nikolaj Karamzin v dialoge epoch i kultur. Colloquia Litteraria Sedlcensia, Studia Minora, volumen X, redakcja Andrzej Borkowski, Joanna Siepietowska, kolegium redakcyjne: Tatsiana Autukhovich, Roman Mnich, Adriana Pogioda-Kołodziejak, Nikolaj Rymar, Danuta Szymonik. Red. monografii Tatsiana Autukhovich. Siedlce: Instytut Neofilologii i Badań Interdyscylinarnych Uniwersytetu Przyrodniczo-Humanistycznego w Siedlcach, Instytut Kultury Regionalnej i Badań Literackich im. Franciszka Karpińskiego, Wydawnictwo IKR[i]B, 2017. 246 s. ISSN 2081-3546, ISBN 978-83-64884-64-1.

Vynikající jubilejní publikaci vytvořili - v těžké konkurenci různých sborníků a periodik reflektujících jubileum Nikolaje Michailoviče Karamzina (1766-1826, tj. 250. výročí narození a 190. výročí úmrtí) - rusisté z polské univerzity v Siedlcích. Celý svazek se skládá ze čtyř oddílů a rubriky Varia (běloruská jména autorů uvádím v ruském znění, jak je to uvedeno $\mathrm{v}$ jejich rusky psaných studiích). Autor této recenze svazek uvedl reflexí pod názvem Perešagnut porog epoch - Nikolaj M. Karamzin i jego pozicija začinatelja a ukázal zde na souvislosti s úvahami T. G. Masaryka v Rusku a Evropě, na anticipační roli Karamzina, na funkci epochy 18. století jako všeobecné dílny umění a na ponorné řeky různých poetik, jež se znovu a znovu vynořují, a na iniciační úlohu cizinců v ruském písemnictví (to je i případ Karamzinova rodu). Natalja Bludilinová (Moskva) analyzovala Karamzinovy studie z časopisu Vestnik Jevropy o dialogu Ruska a Západu, přičemž tradicionalisticky konstatuje zklamání Karamzina na konci tohoto období z nenaplněných cílů osvícenství a Francouzské revoluce. Alla Polosinová (Muzeum L. Tolstého v Jasné Poljaně) porovnala Karamzina a Lva Tolstého jako dva Evropany, ale příliš jí nevěřím, že fakt cestování po Evropě znamená, že se s ní identifikuje: Rus, stejně jako Čech, je Evropanem proto, že žije v Evropě; u Karamzina i Lva Tolstého jde o značně složitý vztah ruského a tzv. evropského, spíše však západoevropského. Ljubov' Sapčenková (Uljanovsk) ve stati Vosem ' s polovinoj ili Karamzin v 1816 godu analyzuje rok, kdy carský historiograf dokončuje osmý svazek Dějin ruského státu jako krizový ve smyslu svě- tového názoru a celkové deprese $\mathrm{z}$ evropského vývoje. Sergej Sokolov (Jekatěrinburg) ukazuje na Karamzinovu polemiku s Lomonosovem jako představitelem „národní samolibosti“ (,narodnoje tščeslavije“) a dokazuje, že - nehledě na polemiku - se ani Karamzin tomuto postoji zcela nevyhnul, zejména pokud jde o nejstarší období Kyjevské Rusi. Irina Rudkovskaja (Tomsk) analyzuje strukturování času v Dějinách Ruského státu v souvislosti s britskou historiografickou tradicí (zejména David Hume, Edward Gibbon). Její zjištění jsou zdánlivě verifikována, ale někdy mám pochybnosti o přímém působení, byt je Karamzinova anglofilie známa a jeho znalost jazyka také, leč někdy přece jen prosvítá silnější zření k ruskému specifiku i v časové strukturaci. Danuta Szymonik (Siedlce) ukazuje na polskou recepci Karamzina, věc značně delikátní (Zorian Dołega-Chodakowski and Joachim Lelewel, později Ryszard Łużny); Poláci ve svých nejosvícenějších projevech si všímali zejména toho, že Karamzinovy dějiny se týkají národa, jenž žil a žije v úzkém kontaktu s Poláky, takže se vlastně týkají i polských dějin. Nevím, jestli to není málo, i když jim velmocenský, byt evropský tón Karamzinových dějin nemusel vyhovovat a jistě svoje kladné hodnocení vyslovovali s jistým sebezapřením. Nicméně nelze nebrat $\mathrm{v}$ úvahu zcela jinou pozici a výjimečnost Polska, jehož jádrové území s Varšavou a Lodží bylo jako Polské království součástí Ruské ř́íše; Poláci byli carovými poddanými, car byl polským králem a jednu dobu - ještě před $\mathrm{Na}$ poleonovým ruským tažením roku 1812 a velkými polskými povstáními - zde byly i zcela jiné vztahy 
mezi šlechtou obou zemí za Alexandra I. a krátce ministra zahraničí Ruské říše Adama Czartoryského (rusk. Čartoryjskij), Alexandrova přítele, jehož pozdější osudy byly však zcela jiné a dosti dramatické. Ještě před nástupem Alexandra I. na ruský trůn vytvořila skupina mladých šlechticů spolu s Alexandrem (A. Czartoryski, hrabě P. A. Stroganov, hrabě V. P. Kočubej, N. N. Novosiĺcev) skupinu, která si žertem říkala Rada spásy, která od roku 1801 rozhodovala o reformách ruského státního systému. Poláci tehdy vytvářeli panslavistické koncepce, na něž později navazoval Jan Kollár (viz o tom polemiky F. Wollmana s Poláky a naši stał Frank Volman i jego polemiki o panslavizme. In: Panslawizm wczoraj, dziś, jutro. Red. Zofia Chyra-Rolicz i Tomasz Rokosz. Siedlce: Uniwersytet Przyrodniczo-Humanistyczny w Siedlcach, Wydział Humanistyczny, Instytut Nauk Społecznych i Bezpieczeństwa, Instytut Filologii Polskiej i Lingvistyki Stosowanej, Instytut Historii i Stosunków Międzynarodowych, 2016, s. 147-160). Studie Jekatěriny Prokofjevové (Dnipropetrovsk/ Dněpropetrovsk) se týká tradic ruského historického dramatu, v níž historik N. M. Karamzin sehrál svou úlohu, ale materiál je chudý, nebot počátky novodobého divadla, a tedy i dramatických textů, jsou poměrně nedávné, takže přiliš nerozumím tvrzení, že ruská dramatika má bohatou tradici s odkazem na známé mystérium Artakserksovo dejstvo (mystéria byla u nás hrána v hlubokém středověku, zde jde o sedmdesátá léta 17. století) předváděné v moskevském dvorském divadle cara Alexeje Michailoviče za iniciace a dohledu německého luteránského pastora Johanna Gottfrieda Gregoryho; hru si ostatně můžeme přečíst na internetu. Samozřejmě ono děsivé zpoždění za ostatní Evropou a bohatství evropské dramatické literatury bijí do očí a na čtyřech stránkách textu nelze tato fakta nijak překonat. Jiná je práce Světlany Salovové (Ufa) o dialogu dramatika s prozaikem a historiografem, tedy mezi M. P. Pogodinem a N. M. Karamzinem - to je vděčné, bohužel jen tematologické pojednání. Motivem světské debaty/besedy se zabývá Tatjana Alpatovová (Moskva) na materiálu Dopisů ruského cestovatele. Je to právě debata, jež se stává posléze i jádrem velké ruské prózy, často ideologicky zaostřený, např. u Turgeněva a Dostojevského. Konečně se dočítáme o Karamzinovi básníkovi: Aleksej Paškurov (Kazaň) zkoumá fenomén vznešeného v Karamzinově poezii (příroda a její sepětí s vnitřním světem člověka, typicky sentimentalisticko-préromantické pojetí, antropologizace, transfery z přírody do společnosti). Další oddíl monografické publikace se týká přesahů Karamzinova díla do dalšího literárního vývoje. Tatjana Avtuchovič (Siedlce) analyzuje N. M. Karamzina v tetralogii M. Aldanova Myslitel (Karamzin je zde zmiňován nebo figuruje jako otevřená nebo skrytá reminiscence). Irina Banach (Grodno) srovnává Pařiž v Dopisech ruského cestovatele a v románu P. Vajla Génius místa; Aleksandr Feduta (Vilnius) ve fascinujícím příspěvku (Rybník času) ukázal na karamzinovské fantazie v básnickém cyklu Borise Chersonského Věnováno Karamzinovi. Ol'ga Joskevič (Grodno) poukázala na spojitosti i podstatné rozdíly v traktování tématu blázince v Dopisech ruského cestovatele a v Dějinách šílenství M. Foucaulta. Roman Mnich (Siedlce) se v několika úvahách (z perspektivy roku 2016) zamýšlí nad Karamzinovou recepcí v 19.-21. století v ruské historiografii a hlavně literární vědě. Podle Mnicha se nám Karamzinova epocha vzdaluje, ale jeho umělecké dílo je stále vděčným předmětem bádání. Obávám se, že je to i jeho historiografická koncepce: Karamzin je tak mnohohranný, že si tato i nová doba, která jednou přijde, vezme $\mathrm{z}$ něho vždy to podstatné a nosné.

Co je v tomto svazku podstatné: na rozdíl od oficiózních karamzinologických publikací, jimiž se to v Rusku i jinde ve světě v karamzinovském jubilejním roce v Rusku i jinde jen hemžilo, stojí tento jakoby na okraji. Autoři nepracují v centrálních institucích, spíše v „provincii“. Problémem je kvalita těchto publikačních výstupů: hlučná prezentace a proti tomu nenápadné studie, většinou in margine mainstreamových témat nebo naopak zobecnuující kontemplace. Jako by přítomný svazek byl „zadním dvorkem“ Varšavy, Sankt-Petěrburgu, Moskvy nebo Prahy, ale o to je průraznější a objevnější. Historie se opakuje: badatelé, kteří byli v minulém režimu vytlačeni jako nebezpeční konkurenti cent- 
rálních institucí bývalého SSSR a jeho satelitů dodnes. Podstatné tkví v detailech, na okraji do provincie (byl mezi nimi svého času i Michail spíše než ve známém středu: Karamzin tu naBachtin do Saranska, nyní bydliště ruského ob- jednou vypadá jinak, jsou nasvěcovány jiné části čana Gérarda Depardieua), došli k tomu nejob- jeho díla a aktualizovány s valencemi v klasické jevnějšímu: tak tomu je jen s malými změnami i moderní literatuře.

\section{prof. PhDr. Ivo Pospíšil, DrSc.}

Ústav slavistiky

Filozofická fakulta, Masarykova univerzita

Arna Nováka 1, 60200 Brno, Česká republika

ivo.pospisil@phil.muni.cz 